\title{
Generations of İstanbul families, the elderly, and the social economy of welfare - CORRIGENDUM
}

\section{Alan Duben}

doi: 10.1017/S0896634600001874. Published by Homer Kitabevi, March 2013.

The original publication of this article contained an error in Table 2. The corrected table is reproduced below:

Table 2. The elderly $(65+)$ in Istanbul, percentages resident in selected household types, $1907^{\star}$ and 2000

\begin{tabular}{|c|c|c|c|c|c|c|}
\hline & \multicolumn{3}{|c|}{1907} & \multicolumn{3}{|c|}{2000} \\
\hline & $\mathrm{M}$ & $\mathrm{F}$ & Total & $\mathrm{M}$ & $\mathrm{F}$ & Total \\
\hline \multicolumn{7}{|l|}{ Household type } \\
\hline Solitary & - & - & 8.1 & 7.9 & 21.6 & 15.7 \\
\hline No-family & - & - & 6.1 & 1.5 & 4.3 & 3.1 \\
\hline Nuclear family & 23.4 & 11.1 & 18.9 & 64.4 & 35.8 & 48.4 \\
\hline (Couple, without offspring)+ & 6.2 & 6.0 & 6.1 & 39.6 & 19.6 & 28.4 \\
\hline (Couple with offspring)+ & 11.1 & - & 6.1 & 21.2 & 6.7 & 13.1 \\
\hline Extended family & 22.2 & 61.1 & 40.0 & 7.4 & 25.5 & 17.5 \\
\hline (Single parent with couple)+ & 11.1 & 58.2 & 32.4 & 5.4 & 24.5 & 16.1 \\
\hline Multiple family & 33.3 & 21.7 & 27.0 & 19.4 & 12.5 & 15.3 \\
\hline (Stem family)+ & 24.7 & 6.7 & 16.2 & 13.9 & 8.1 & 10.6 \\
\hline Elders with offspring (est.) & 76.5 & 83.5 & 79.7 & 51.0 & 54.5 & 52.8 \\
\hline Elders without offspring (est.) & 23.5 & 16.5 & 20.3 & 49.0 & 45.5 & 47.2 \\
\hline Numbers & 81 & $67++$ & 148 & 8,222 & 10,459 & 18,681 \\
\hline
\end{tabular}

* The 1907 sample is too small to use as a basis for reliable statements, especially in comparison with 2000 . There are, however, no other household data available for that period. The intention in presenting the 1907 figures is to provide a suggestive basis for discussion. + percentages of total.

++ elderly females underreported in 60-75 age cohorts. See Figure 1.

Sources: Ottoman census rosters for the permanent Muslim population of Istanbul, 1907, and Turkish census, Istanbul census file, 2000. This table does not include unclassifiable households.

\section{Reference}

Duben, Alan. Generations of Istanbul Families, the Elderly, and the Social Economy of Welfare. New Perspectives on Turkey. Homer Kitabevi. 48 (2013): 5-51. 